\title{
Short Communication: \\ Proximate analysis, amino acid profile and albumin concentration of various weights of Giant Snakehead (Channa micropeltes) from Kapuas Hulu, West Kalimantan, Indonesia
}

\author{
WAHYU WIRA PRATAMA ${ }^{1}$, HAPPY NURSYAM ${ }^{2}$, ANIK MARTINAH HARIATI ${ }^{3}$, R. ADHARYAN ISLAMY ${ }^{3, \bullet}$, \\ VERYL HASAN $\mathbf{N}^{4, \vee v}$ \\ ${ }^{1}$ Program of Aquaculture, Faculty of Fisheries and Marine Science, Universitas Brawijaya. Jl. Veteran No.16, Malang 65145, East Java, Indonesia \\ ${ }^{2}$ Department of Fishery Products Technology, Faculty of Fisheries and Marine Science, Universitas Brawijaya. J1. Veteran No.16, Malang 65145, East \\ Java, Indonesia \\ ${ }^{3}$ Departement of Aquaculture, Faculty of Fisheries and Marine Science, Universitas Brawijaya. J1. Veteran No.16, Malang 65145, East Java, Indonesia. \\ Tel.: +62-341-553-512, Fax.: +62-341-556-837, `email: r.adhariyan@ub.ac.id \\ ${ }^{4}$ Department of Fish Health Management and Aquaculture, Faculty of Fisheries and Marine Science, Universitas Airlangga. Kampus C Unair, Jl. \\ Mulyosari, Surabaya 60113, East Java, Indonesia. Tel.: +62-31-315911541, Fax.: +62-31-5965741, "vemail: veryl.hasan@ fpk.unair.ac.id
}

Manuscript received: 13 November 2019. Revision accepted: 23 February 2020.

\begin{abstract}
Pratama WW, Nursyam H, Hariati AM, Islamy RA, Hasan V. 2020. Short Communication: Proximate analysis, amino acid profile and albumin concentration of various weights of Giant Snakehead (Channa micropeltes) from Kapuas Hulu, West Kalimantan, Indonesia. Biodiversitas 21: 1196-1200. Fish is an important foodstuff due to its nutritional value and high protein. One of popular fish as a foodstuff in tropical Asia is giant snakehead fish (Channa micropeltes). This study aims to examine the proximate composition, amino acid profile, and albumin concentration of giant snakeheads in various weights and to determine the best weight of giant snakeheads according to the proximate, amino acid, and albumin concentration. This research used natural-caught giant snakehead as a material of study, which was categorized into 4 weight sizes consisting of 4-5 grams (B1), 6-14 grams (B2), 15-34 grams (B3), 35-300 grams (B4). Based on the results of the test, the highest water content was found in B1 of $80.5 \%$, the highest levels of protein and fat were in the B4 group of $16.8 \%$ and $1.7 \%$, respectively. The highest total amino acid profile was found in B4, with the highest composition of essential amino acids, lysine, which was $2.02 \%$, while the composition of the highest non-essential amino acid in glutamate was $3.60 \%$. The highest albumin levels were in the B4 group which was $16.7 \%$. According to the result of this research, the best weight to consume according to the proximate analysis (Protein, fat content), amino acid profile, and albumin concentration is a giant snakehead at the weightiest of 35-300 grams (B4).
\end{abstract}

Keywords: Albumin level, amino acid, Channa micropeltes, Kapuas Hulu, West Kalimantan

\section{INTRODUCTION}

The giant snakehead fish (Channa micropeltes) is one of the foodstuffs in tropical Asia (Benziger et al. 2011). They belong to Channidae in Channiformes and have been distributed in the fresh waters of Southeast Asia, such as the Malaysia peninsula, Menam River, Mekong River, Sumatra Island (Jiang et al. 2016). The giant snakehead is also popular and widely available in the area of West Kalimantan (Roberts 1989). Based on statistics from the Department of Maritime Affairs and Fisheries of West Kalimantan Province (2014-2017), the total of Giant Snakehead production from natural catches has increased significantly, total catches of 1,924 tons in 2015, and increased to 6,572 tons or of $241.57 \%$ in 2017 .

Channa micropeltes are consumed for their dietary proteins, mainly protein albumin (Fitriyani 2018). Some studies found that consuming snakeheads is good for human body to keep healthy (Jacob et al. 2008). Consuming snakehead also lead to accelerating the wound healing process (Nicodemus et al. 2015). Nevertheless, the snakehead can also enhance dermal wound healing, to reduce post-operative pain and discomfort (Jais et al. 1994), and treatment of skin conditions such as eczema. The studies on the determination of tensile strength of healed wounds treated with giant snakeheads have indicated the efficacy of the fish in wound healing (Baie and Sheikh 2000a, 2000b).

In West Kalimantan, giant snakeheads (Channa micropeltes) were caught in various weight ranging from small to adult, even reaching weights $>2 \mathrm{~kg}$ per individual. The bodyweight of the snakehead affects the content of albumin (Asikin and Kusumaningrum 2018). However, practical information about the chemical composition such as albumin and amino acid profile of the Giant Snakehead (Channa micropeltes) is not known based on variations in size. So this study aims to analyze the proximate, amino acid profile and albumin levels of giant snakeheads in various sizes. 


\section{MATERIALS AND METHODS}

\section{Sample preparation}

Giant snakehead (Channa micropeltes) was obtained by natural catches from West Kalimantan Province in September 2019 (Rain season). The fish used are sorted first into four size groups consisting of weights of 4-5 grams (S1), 6-14 grams (S2), 15-34 grams (S3), 35-300 grams (S4). Then the fish was measured using a measurement set and then washed thoroughly in running water. The meat and intestinal digestion of the fish were taken and stored in a jar for immediate testing of amino acid profiles, albumin content, proximate composition, and protease enzyme activity.

\section{Analysis of proximate composition}

Proximate composition of giant snakehead was determined using standard analytical methods including moisture, protein, ash, fat, and carbohydrate (Patricia et al. 2014). Determination of moisture was done through drying $10 \mathrm{~g}$ of drained fish meat in an oven at $100-105^{\circ} \mathrm{C}$ for $3-5$ hours, then chilled in desiccators and weighed. The materials were then dried again in the oven for 30 minutes, chilled in desiccators, and weighed. This experiment was carried out in three repetitions until the weight was constant. The calculation for moisture used this formula:

$$
\text { Moisture }=\frac{\text { Beginning weight }- \text { Ending weight }}{\text { Ending weight }} \times 100 \%
$$

The protein content was determined using the Kjeldahl method of nitrogen $(\mathrm{N})$ analysis. The 0.5 gram of sample was weighed carefully, then added into Kjeldahl flask 100 $\mathrm{mL}$. Then, an approximately 1 gram mixture of selenium and $10 \mathrm{~mL}$ of concentrated $\mathrm{H}_{2} \mathrm{SO}_{4}$ (technical) were added. Khjedhal flask with its content was shaken until H2SO4 wetted all the samples. Then it was destructed in the acid cupboard until transparent. The solution was left cold poured into volumetric flask $100 \mathrm{~mL}$ and rinsed by distilled water, then added distilled water until sign. An Erlenmeyer consisted of $10 \mathrm{~mL} \mathrm{H}_{3} \mathrm{BO}_{3} 2 \%+4$ drops of mixture indicator solution in Erlenmeyer $100 \mathrm{~mL}$ was prepared. 5 $\mathrm{mL} \mathrm{NaOH} 30 \%$ and $100 \mathrm{~mL}$ distilled water was pipetted, then distilled until the container was filled about $50 \mathrm{~mL}$. Then, the container and its content were titrated using $\mathrm{HCl}$ or $\mathrm{H}_{2} \mathrm{SO}_{4} 0,0222 \mathrm{~N}$ solution until the solution changed into light red and did not disappear for 30 minutes. Calculating using the formula below :

$$
\text { Protein content }(\%)=\frac{V \times N \times 0.014 \times 6.25 \times P}{\text { sample }(\text { gram })} \times 100 \%
$$

While, $\mathrm{V}$ is sample titration volume, $\mathrm{N}$ is solution normality of $\mathrm{HCl}$, or $\mathrm{H} 2 \mathrm{SO} 40,0222 \mathrm{~N}$ and $\mathrm{P}$ is dilution factor $=100 / 5$.

Determination of ash content by the incineration of a dried sample $(5 \mathrm{~g})$ in a muffle furnace (Pyrolabo, France) at $550^{\circ} \mathrm{C}$ for $12 \mathrm{~h}$ until the ash turned white. Fat content was determined by hexane extraction for seven $\mathrm{h}$ in a Soxhlet apparatus. Calculating of carbohydrates value carried out using the formulas (FAO 2002):
Carbohydrate $=100(\%$ moisture $+\%$ proteins $+\%$ fat $+\%$ ash

\section{Amino acid profile analysis}

Determination of the amino acid composition used HPLC based on AOAC (2005). Before being used, the HPLC device must be rinsed with eluents. Likewise, the syringe was rinsed with distilled water before being used. Amino acids analysis used HPLC that consists of 4 stages. The stages were the protein hydrolyzate production, the drying, the derivatization, and the injection stage (AOAC, 2005). $5 \mu \mathrm{L}$ of filter was injected into the HPLC, and let the separation process of all amino acids finish. The time needed was around 25 minutes. Calculation of the amino acid concentration present in the material was by making a standard chromatogram using ready-made amino acids that undergo the same treatment as the sample. Quantification formula of the amino acid content in the ingredients was as follows:

$$
\% \text { Amino acid }=\frac{\text { The area of the sample } \times \text { C } \times \text { Fp x BM x } 100 \%}{\text { Standard area x sample weight }}
$$

\section{Albumin levels}

The analysis of albumin was based on the modification of the published method (Doumas et al. 1971). The determination test of albumin was conducted on the flesh. The extraction of albumin was based on acid solvent extraction. The flesh of snakehead fish at each size category was cleaned and washed in tap water until there was no blood nor mucus, and then was cut to smaller pieces. The flesh was then smoothed using a blender and mixed with solvent at a ratio of 1:1 $(100 \mathrm{~mL}$ solvent: $100 \mathrm{~g}$ fish). To separate liquid and dregs, a sample from each treatment was filtered. the liquid was separated from its oil by adding hexane solvent for $200 \mathrm{~mL}$ and shaken for 30 minutes. After performing two phases, the oil was separated by the funnel. Extract liquid was dried in an oven at a temperature of $60-70^{\circ} \mathrm{C}$. The albumin content was measured using the absorbance in the sample at $578 \mathrm{~nm}$ wavelength. A total of $2.5 \mathrm{~mL}$ of BCG reagent $0.01 \%$ was added to $0.5 \mathrm{~mL}$ albumin extract and left for 10-15 minutes. The absorption level of the mixture was measured at $578 \mathrm{~nm}$ wavelength. Furthermore, the obtained data were analyzed using descriptive methods. Determination of enzyme activity was conducted by the homogenizing fish intestine in normal saline at a ratio of $1 \mathrm{~g}$ sample and $9 \mathrm{~mL}$ normal saline and centrifuged at $10,000 \mathrm{x}$ g for $20 \mathrm{~min}$ to obtain a clear supernatant which was analyzed for enzyme activities.

\section{RESULTS AND DISCUSSION}

\section{Proximate composition result}

The result of the proximate analysis of giant snakehead (Channa micropeltes) in this study is shown in Table 1. The nutrition of giant snakehead seems to be proportional to the size of the species with the weightiest fish contain the highest protein value while the lightest fish had the lowest value of protein. It also happened to the fat content. 
On the other hand, the higher contains carbohydrate showed different result in which the lightest weight fish contain more carbohydrate than the weightiest fish.

Table 1 showed that the moisture ranged from 78.6 to $80.5 \%$ with the highest value was found in the lightest weight fish (B1) $(80.5 \%)$ and the lowest was found in the weightiest $(78.6 \%)$. Another study also found that the weightiest snakehead contains high moisture, i.e. $80.41 \%$ which was more than that of the lightest (Suwandi et al. 2014). The highest fat content was shown in the B4 group $(1.7 \%)$, and the lowest was showed in the B1 group $(0.8 \%)$. The data above showed that low-fat fish had higher water content (Osman et al. 2001). Fats are high-energy nutrients that can be utilized to partially substitute for protein in aquaculture feeds (Craig and Helfrich, 2002). Fats have many roles, including energy supply, structure formation and precursors to many reactive substances (Bureau and Cho, 2003).

The protein content ranged from 13.7 to $16.8 \%$, with the highest protein content was found in the weighest group (B4), which is $16.8 \%$ and the lowest was found in the lightest weight group (B1), namely $16.8 \%$. Protein requirements are generally higher for smaller as well as early life stage fish but when fish grow larger, the protein requirements usually decrease (Craig and Helfrich, 2002). Protein requirements also vary refer to water temperature, water quality, and rearing environment, as well as the genetic composition and feeding rates of the fish. It is used for fish growth if adequate levels of carbohydrates (energy) and fats are present in the diet. If not, the more expensive protein can be used for energy and life support rather than growth. The result was similar to another study that showed the protein content was higher in the weighest fish than that of the lightest weight (Mustafa et al. 2012).

Hitherto, protein and fat are the primary nutrients in fish, and their level helps to define the nutritional status of a particular organism (Aberoumand and Pourshafie 2010), where proteins are required for fetal development and growth. Dietary protein is needed principally for growth, metabolism, and maintenance, especially in young ones (Adefemi 2011) and fat as energy resources (Ismail 2005). According to the data above, we assumed that the best group of giant snakeheads to consume is B4 since it contains more protein and fat than the other group.

However, the high protein content in giant snakehead meat was influenced by the type of food, habitat, and food availability (Chasanah et al. 2015). A study assumes that in their natural habitat, rainy season will naturally stimulate snakehead to gain their weight for development of reproduction (Bijaksana 2015) supported by rich availability of their natural food such as fish, frogs, snakes, insects, earthworms and crustaceans (Amilhat and Lorenzen 2005) in rainy season. Lack food of snakehead in the top of the dry season will be making this fish convert most of their energy to the maturation of the final oocyte, it will cause decrease in body weight of snakehead (Bijaksana 2015). In other words, snakehead caught in rainy season is more nutritious than dry season.

\section{Amino acid profile result}

The result of the amino acid profile of giant snakehead (Channa micropeltes) in this study is shown in Table 2. The result shows that the giant snakehead contains 15 amino acids (Table 2). These amino acids list in the sample are threonine, valine, methionine, L-leucine, leucine, phenylalanine, histidine, lysine, arginine, aspartic acid, serine, glutamate, glycine, alanine, and tyrosine respectively.

Snakehead fish is an obligatory air-breather and predaceous fish that resides in swamps, slow-flowing streams, and in crevices near riverbanks, which, in taxonomy, belongs to the family Channidae (Qasim 1966). The diet type of fish contributes to the nutritional content of meat-related to digestibility and the content of essential and non-essential giant snakehead amino acids (Table 2). Overall the weighest fish group (B4) has the highest amino acid concentration when it is compared to others. The highest concentration of essential amino acids found in lysine $(2.02 \%)$. The similar results of studies of the same species of Channa micropeltes showed the highest composition of essential amino acids of lysine (Zuraini 2006). Various studies have proven the role of lysine on growth (Palavesam 2008; Malik et al. 2017; Hien et al. 2018). Besides, lysine is known to be one of amino acids that can induce albumin synthesis (Murray et al. 2009). The highest non-essential amino acid content is found in glutamate $(3.60 \%)$. The results of this research are similar to another study showing more glutamate content in the weighest snakehead (Gam et al. 2005; Zuraini 2006). Glutamate gives savory flavor in giant snakehead meat (Zhao 2016). Glutamate plays a central metabolic role in the brain (Krebs 1935), where glutamate uptake activity in brain cells is very high (Stern et al. 1949), and that glutamate has an excitatory role (Hayashi 1954; Curtis et al. 1959, 1960).

Table 1. Proximate Analysis Results (\%) Giant snakehead in various weights

\begin{tabular}{lcccc}
\hline Sample & $\begin{array}{c}\text { Moisture } \\
(\boldsymbol{\%})\end{array}$ & $\begin{array}{c}\text { Protein } \\
(\boldsymbol{\%})\end{array}$ & $\begin{array}{c}\text { Fat } \\
(\boldsymbol{\%})\end{array}$ & $\begin{array}{c}\text { Ash } \\
(\boldsymbol{\%})\end{array}$ \\
\hline B1 & $80.5 \pm 0.4$ & $13.7 \pm 0.2$ & $0.8 \pm 0.1$ & $1.9 \pm 0.1$ \\
B2 & $79.8 \pm 0.9$ & $14.2 \pm 0.2$ & $1.0 \pm 0.1$ & $2.0 \pm 0.1$ \\
B3 & $79.8 \pm 1.0$ & $14.9 \pm 0.4$ & $1.3 \pm 0.2$ & $1.9 \pm 0.1$ \\
B4 & $78.6 \pm 0.7$ & $16.8 \pm 0.2$ & $1.7 \pm 0.2$ & $1.3 \pm 0.3$ \\
\hline
\end{tabular}




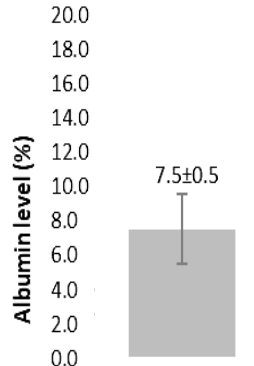

B1

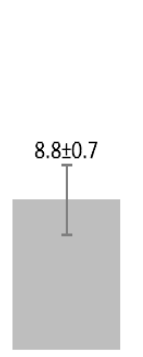

B2
B4

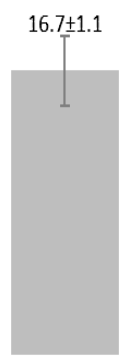

Fish Weight

Figure 1. Albumin level (\%) and giant snakehead protease enzyme activity in various weight variations

Table 2. Giant snakehead amino acid profile various weight weights (\%)

\begin{tabular}{lcccc}
\hline Amino acid & $\mathbf{B 1}$ & $\mathbf{B 2}$ & $\mathbf{B 3}$ & $\mathbf{B 4}$ \\
\hline Threonine & $0.59 \pm 0.01$ & $0.61 \pm 0.01$ & $0.65 \pm 0.01$ & $0.88 \pm 0.01$ \\
Valine & $0.70 \pm 0.00$ & $0.73 \pm 0.01$ & $0.76 \pm 0.02$ & $1.01 \pm 0.02$ \\
Methionine & $0.41 \pm 0.00$ & $0.42 \pm 0.00$ & $0.45 \pm 0.01$ & $0.65 \pm 0.01$ \\
L-leucine & $0.61 \pm 0.00$ & $0.63 \pm 0.00$ & $0.65 \pm 0.00$ & $0.95 \pm 0.00$ \\
Leucine & $1.08 \pm 0.01$ & $1.12 \pm 0.02$ & $1.17 \pm 0.04$ & $1.65 \pm 0.04$ \\
Phenylalanine & $0.54 \pm 0.01$ & $0.56 \pm 0.00$ & $0.62 \pm 0.04$ & $0.87 \pm 0.04$ \\
Histidine & $0.42 \pm 0.00$ & $0.43 \pm 0.00$ & $0.48 \pm 0.00$ & $0.63 \pm 0.02$ \\
Lysine & $1.24 \pm 0.01$ & $1.30 \pm 0.02$ & $1.36 \pm 0.00$ & $2.02 \pm 0.04$ \\
Arginine & $0.4 \pm 0.00$ & $0.42 \pm 0.00$ & $0.46 \pm 0.00$ & $0.48 \pm 0.03$ \\
Aspartic acid & $1.30 \pm 0.00$ & $1.39 \pm 0.01$ & $1.48 \pm 0.00$ & $2.16 \pm 0.02$ \\
Serine & $0.52 \pm 0.00$ & $0.54 \pm 0.00$ & $0.60 \pm 0.00$ & $0.80 \pm 0.04$ \\
Glutamate & $2.20 \pm 0.00$ & $2.35 \pm 0.05$ & $2.47 \pm 0.00$ & $3.60 \pm 0.07$ \\
Glysine & $0.78 \pm 0.01$ & $0.86 \pm 0.03$ & $0.95 \pm 0.00$ & $1.10 \pm 0.04$ \\
Alanine & $0.84 \pm 0.01$ & $0.88 \pm 0.01$ & $0.96 \pm 0.00$ & $1.26 \pm 0.05$ \\
Tyrosine & $0.42 \pm 0.00$ & $0.46 \pm 0.01$ & $0.47 \pm 0.00$ & $0.66 \pm 0.02$ \\
\hline
\end{tabular}

\section{Albumin content}

The result of the albumin content of giant snakehead (Channa micropeltes) in this study is shown in Figure 1. The result shows that the weighest giant snakehead (B4) contains the highest albumin (16.7\%) compared to the lightest weight group (B1) $(7.5 \%)$ (Figure 1). Albumin is a plasma protein that is used in the medical world to accelerate the process of wound healing after surgery and improve hypoalbuminemia status. Meanwhile, the difference in body weight of giant snakehead affects the level of albumin in this study, and it is in accordance with the results of research of other species in the same genus (Channa striata) (Rohmawati 2010).

Giant snakehead is a species of the Canidae family that has high albumin potential (Firlianty 2016). High or low albumin is influenced by nutrition, hormones, and the presence or absence of disease (Peters 2008). Nutrients in feed, especially certain amino acids, arginine, lysine, phenylalanine, threonine, and tryptophan, can induce albumin synthesis (Firlianty 2013). Giant snakehead as a top predator and carnivorous species feed on various food available in nature (Solovyev et al. 2014). Bigger giant snakeheads may select particular food that contains higher protein, and this results in higher albumin protein concent. Many influencing factors are fish type, type of solvent, extraction method, temperature, filtering, drying, cutting the meat of snakehead fish, the weight of fish (Asikin and Kusumaningrum 2017). The protein and albumin content in fish meat are influenced by the type of food, habitat, as well as food availability but not by sex differences (Chasanah et al. 2015). This research used snake-head fish from the traditional market in Bekasi dan Tangerang district, therefore, the level of stress and the natural conditions of the environment of the lives of fish are very influential to the height of albumin content (Asikin and Kusumaningrum 2017).

In conclusion, the highest water content is in B1 at $80.5 \%$. The highest levels of protein and fat are found in the B4 group at $16.8 \%$ and $1.7 \%$. The highest ash content is in the B2 group at $2.0 \%$. Carbohydrates are highest in the $\mathrm{B} 1$ group at $3.1 \%$. Overall, the highest amino acid profile is found in B4, with the highest essential amino acid, lysine, i.e. $2.02 \%$, while the highest non-essential amino acid is found in glutamate, i.e. $3.60 \%$. The highest albumin levels are in the B4 group, namely $16.7 \%$. The highest protease activity is found in B1 namely $0.531 \mu \mathrm{mol}$ tyrosine/mg minute enzyme.

\section{REFERENCES}

Aberoumad A, Pourshafi K. 2010. Chemical and proximate composition properties of different fish species obtained from Iran. World J Fish Mar Sci 2: 237-239.

Adefemi OS. 2011. Chemical composition of Tilapia mosambis fish from major dams in Ekiti-State, Nigeria. African J Food Sci 5: 550-554.

Amilhat E, Lorenzen K. 2005. Habitat use, migration pattern and population dynamics of chevron snakehead Channa striata in a rainfed rice farming landscape. J Fish Biol 67: 23-34.

Asikin AN, Kusumaningrum I. 2017. Karakteristik ekstrak protein ikan gabus berdasarkan ukuran berat ikan asal DAS Mahakam Kalimantan Timur. Jurnal Pengolahan Hasil Perikanan 1: 137-142. [Indonesian]

Baie SH, Sheikh K A. 2000a. The wound healing properties of Channa striatus-cetrimide cream-wound contraction and glycosaminoglycan measurement. J Ethnopharmacology 73: 15-30.

Baie SH, Sheikh K A. 2000b. The wound healing properties of Channa striatus-cetrimide cream-tensile strength measurement. J Ethnopharmacology 71: 93-100.

Benziger A, Philip S, Raghavan R, Ali PHA, Sukumaran M, Tharian JC, Dahanukar N, Baby F, Peter R, Devi KD, Radhakrishnan KV, Haniffa MA, Britz R, Antunes A. 2011. Unraveling a 146 Years Old Taxonomic Puzzle: Validation of Malabar Snakehead, Species-Status and Its Relevance for Channid Systematics and Evolution. PLoS ONE 6 (6): e21272. DOI: 10.1371/journal.pone.0021272.

Bijaksana U, Hidayaturrahmah, Sari DK. 2015. Re-stocking model of snakehead farming, Channa striata Blkr in the swamp Bangkau of South Kalimantan Province. Glob J Fish Aquacult 3: 198-204.

Bureau DP, Cho CY. 2003. An introduction to nutrition and feeding of fish. Fish Nutrition Research Technical Report Laboratory, University of Guelph. Guelph, ON, Canada

Chasanah E, Nurilmala M, Purnamasari AR. Fithriani D. 2015. Komposisi kimia, kadar albumin dan bioaktivitas ekstrak protein ikan gabus (Channa striata) alam dan hasil budaya. JPB Kelautan dan Perikanan 2: 123-132. [Indonesian]

Craig S, Helfrich LA. 2002. Understanding fish nutrition, feeds and feeding. Technical Report Virginia State University Petersburg (VA). Virginia.

Curtis DR, Phillis JW, Watkins JC. 1959. Chemical excitation of spinal neurones. Nature 4661: 611-612.

Curtis DR, Phillis JW, Watkins JC. 1960. The chemical excitation of spinal neurones by certain acidic amino acids. J Physiol 3: 656-682. 
Doumas BT, Watson WA, Biggs HG. 1971. Albumin standards and the measurement of serum albumin with bromcresol green. Intl Clin Chem 31: 87-96.

Firlianty. 2013. Chemical composition and amino acid profile of Channidae collected from Central Kalimantan, Indonesia. Intl J Sci Technol 2: 25-29.

Firlianty. 2016. Vacuum drying albumin powder of snakehead (Channa micropeltes) potential for wound healing from Central Kalimantan, Indonesia. Int J Chem Tech Res 9: 263-269.

Fitriyani E, Deviarni IM. 2018. Pengaruh suhu dan waktu ekstraksi ikan giant snakehead (Channa micropeltes) menjadi serbuk albumin. Jurnal Galung Tropika 2: 102 - 114. [Indonesian]

Gam LH, Leow CY, Baie S. 2005. Amino acid composition of snakehead fish (Channa striatus) of various sizes obtained at different times of the year. Malays J Pharmaceut Sci 3: 19-30.

Hayashi T. 1954. Effects of sodium glutamate on the nervous system. Keio J Med 3: 183-192.

Hien T, Tu T, Nguyen K, Van, Minh PT. 2018. Dietary methionine and lysine requirement of snakehead (Channa striata) fingerlings. Intl J Sci Res Publ 8: 795-805.

Ismail HM. 2005. The role of omega-3 fatty acids in cardiac protection An overview. Front Biosci 10: 1079-1088.

Jais AMM, McCulloch R, Croft K. 1994. Fatty acid and amino acid composition in haruan as a potential role in wound healing. Gen Pharmacol Vasc Syst 25(5): 947-950.

Jiang S, Zhang K, Ruan Z, Xu J, You X, Shi Q. 2016. The complete mitochondrial genome of Indonesian snakehead, Channa micropeltes (Channiformes, Channidae). Mitochondrial DNA Part B Resour 1, 2016: 556-557.

Krebs HA. 1935. Metabolism of amino-acids: The synthesis of glutamine from glutamic acid and ammonia, and the enzymic hydrolysis of glutamine in animal tissues. Biochem J 8: 1951-1969.

Malik MA, Sharma HK, Saini CS. 2007. High-intensity ultrasound treatment of protein isolate extracted from dephenolized sunflower meal: Effect on physicochemical and functional properties Ultrasonics Sonochem 39: 511-519.

Murray RK. Daryl KG, Victor WR. 2009. Biokimia Harver (Ed.27) Penerbit Buku Kedokteran (EGC), Jakarta. [Indonesian]

Mustafa A, Widodo MA, Kristianto Y. 2012. Albumin and zinc content of snakehead fish (Channa striata) extract and its role in health. Intl J Sci Technol 1: 1-8.
Nicodemus, Andrie M, Luliana S. 2015. Uji efek penyembuhan luka sayat ekstrak ikan giant snakehead (Channa Micropellets) secara oral pada tikus putih jantan wistar. Jurnal Mahasiswa Farmasi Fakultas Kedokteran UNTAN 4: 1-14. [Indonesian]

Osman H, suriah AR, Law EC. 2001. Fatty acid composition and cholesterol content of selected marine fish in Malaysian waters. Food Chem 73: 55-60.

Palavesam A, Beena S, Immanuel G. 2008. Effect of L-Lysine supplementation with different protein levels in diets on growth, body composition and protein metabolism in pearl spot Etroplus suratensis. Turk J Fish Aquat Sci 8: 133-139.

Patricia O, Lessoy Z, Rose MM, Ryta D, Sébastien N. 2014. Proximate composition and nutritive value of leafy vegetables consumed in Northern Côte D'ivoire. Europ Sci J 10: 212-227.

Peters T. 2008. All about Albumin: Biochemistry, Genetics, and Medical Applications. Academic Press. San Diego, CA.

Qasim. 1966. The growth of the freshwater murrel, Ophiocephalus punctatus Bloch Hydrogiologica 27: 289-316.

Roberts TR. 1989. The Freshwater Fishes of Western Borneo (Kalimantan Barat, Indonesia). Academy of Science, San Francisco.

Rohmawati S. 2010. The Content of Snakehead Fish Albumin (Ophiocephalus striatus) is Based on Fish Body Weight. [Thesis]. State University of Malang, Malang. [Indonesian]

Solovyev MM, Kashinskaya EN, Izvekova GI, Gisbert E, Glupov VV. 2014. Feeding habits and ontogenic changes in digestive enzymes patterns in five freshwater teleosts. J Fish Biol 85: 1395-1412.

Stern JR, Eggleston LV, Hems R, Krebs HA. 1949. Accumulation of glutamic acid in isolated brain tissue. Biochem $\mathrm{J}$ 4: 410-418.

Suwandi R, Nurjanah, Winem M. 2014. Proporsi bagian tubuh dan kadar proksimat ikan gabus pada berbagai ukuran. Jurnal Pengolahan Hasil Perikanan Indonesia 17: 22-28. [Indonesian]

Zhao CJ, Scheber A, Ganzle MG. 2016. Formation of taste-active amino acids, amino acid derivatives and peptides in food fermentations. Food Res Int 89: 39-47.

Zuraini A, Somchit MN, Soliha MH, Goh YM, Arifah AK, Zakaria MS, Somchit N, Rajion MA, Zakaria ZA, Mat JAM. 2006. Fatty acid and amino acid composition of three local Malaysian Channa spp. Fish. Food Chem 4: 674-678. 